\title{
Role of Discipline and Educational Method on Vocational High School Students' Success in an Anesthesia Course
}

Gökcen BAŞARANOĞLU1', Metin BAŞARANOĞLU²

${ }^{1}$ Department of Anesthesiology and Reanimation, Bezmialem Vakif University Faculty of Medicine, Istanbul, Turkey

${ }^{2}$ Department of Internal Medicine and Gastroenterology, Bezmialem Vakif University Faculty of Medicine, Istanbul, Turkey

\section{ABSTRACT}

Objective: The goal of this study is to reveal the relationship between discipline and teaching method and between vocational high school technical students' success in an anesthesia course and levels of following the lessons.

Methods: A questionnaire was filled out by first-year technical students in an anesthesia course for situational awareness evaluation at the beginning of the term. Oral presentations were supported by catechetics, reward systems, etc. to ensure active participation.

Results: While the students' success rate was $91.9 \%$, the dissatisfaction rate was $4 \%$. The students stated that they were most satisfied $(100 \%)$ with the rewarding part of the theoretical lessons.

Conclusion: Anesthesiology requires discipline for achieving success. Students' course success on anesthesia can be enhanced using a student-centered learning and reward system.

Keywords: Discipline, success, anestesia, lesson

\section{Introduction}

The anesthetic technician department is responsible for making sound and correct decisions and requires attention. Individuals having a developed sense of responsibility and manual skill, who can build good relationships with their workmates and patients, and who can work indoors should choose this department. Vocational high school (VHS) anesthesia department students should notice sudden cases during the operation and inform them to the anesthesiologist on time, they should have a capacity to work with anesthesia devices and monitors, they should establish vascular access, they should maintain airway, and they should be well aware of the devices and drugs used. In fact, anesthesia education is difficult and necessitates discipline. The university environment and working at the hospital may make the adaptation process more difficult for some students. In this study, the relationship between anesthesia education discipline and success of VHS freshmen.

\section{Methods}

A questionnaire was filled out by first-year students of the anesthesia department before and after the term and the situation was determined (Appendix 1). Questions such as the satisfaction of the students from the department, whether they can focus on the lessons sufficiently, and whether they have a difficulty in understanding and following the lessons were included. Trainee reports were given to the students for the practical lesson, and they were allowed to see a certain number and kind of patients and practices. A technician was assigned to guide a student for teaching the hierarchical order in the group. Anesthesia practice was put back for calibration of the device and patient preparation. Students were encouraged to ask questions in the theoretical lessons. Active participation was provided by encouraging questions and answers with rewards and by making eye contact with the students. It was attempted to 
determine improvements in teaching by receiving feedback at the end of the lessons. Questionnaires were made about the teaching method of the anesthesia teacher so that he improved himself.

\section{Results}

Eighteen first-year students from VHS answered the questionnaire. The median age of the students was 18 years (min: 17, max: 23). There was one student who was not satisfied with the department. Seventeen students found what they expected from the department. The rate of the students who had difficulties in understanding the lessons was $23 \%$. In addition, $29 \%$ of the students thought that practice lessons were insufficient. One student felt disturbed and unhappy. Moreover, 29\% of the students felt guilty of not studying sufficiently, not being able to focus on the lessons, and not finding time for the lessons. The average of only one student who changed the school in the middle of the term was below 50 points. The success rate of the students was $91.9 \%$, and the dissatisfaction rate from assessment and evaluation was 4\% (1). The satisfaction rate from the anesthesia teachers was $100 \%$. The students who got low marks thought that was because they could not focus on the lessons sufficiently, they were tired, and they could not study enough. In total, $33 \%$ of the students joined all the lessons. Totally, $43 \%$ of the students were medical VHS graduates. None of the students wanted anesthesia lesson as a distant training.

\section{Discussion}

The anesthesia department requires attention and necessitates discipline and hierarchy. The mean age of VHS students was 18 years. The specific characteristics of the young student's entering into a new environment and the difficulties of the department sometimes made the students disobey and not attend the class. Maintaining discipline is mandatory in the operation rooms, which necessitates military discipline, and a minute inattention may result in morbidity and mortality. This discipline has to be taught and practiced. Therefore, students displaying such behavior were warned.

Presentation techniques should be used in place for the students to understand better. Instructional objectives were put forward in the initial slides of each anesthesia theoretical lesson. Attendance was mandatory, and those who gave correct answers to the questions in the lessons were rewarded. No punishment was given, and the students were encouraged to ask questions so that their self confidence improved. The teacher made eye contact with all the students. It was attempted to not exceed $20 \mathrm{~min}$ for the theoretical part of the lesson, and questions were asked and examples were given from daily practice in the remaining $20 \mathrm{~min}$. The lessons were not combined, and the teacher adjusted the tone of his voice so that the students continued giving their attention. The teacher gave the lecture walking around the class instead of sitting.

Hotaman et al. (1), in their study about teacher enthusiasm and the level of achievement motivation, detected that there was a positive correlation between achievement motivation and teacher enthusiasm. Şen et al. (2) found that a teacher's thinking, questioning, criticizing, continuously renewing themselves, and those who are open-minded are effective teachers (2). The studies indicated that $83 \%$ of those that were learned were visually learned and the more senses included in learning the more effective the learning would be (3). The lectures were given in accordance with the points stated in the anesthesia department theoretical lessons. Feedback was taken from the students at the end of the lessons, and it effective methods of delivering the lecture more effectively were discussed. The trainees, working in accord with the technicians, were provided with a training record book application for practical lessons. In the training record book, seeing a certain number of patients, performing device calibration, and conducting tasks suitable to the term level were standardized. It was allowed to conduct desk study under the control of a technician and physician. The reinforcement of the information was provided by mentioning the mistakes at the same time.

Ülger et al. (3), in a study conducted for the education of medical vocational lessons, suggested the importance of visual aids and interactive teaching. In our study, the teachers paid attention to these points, and they saw the positive effect of this on achievement of the students.

\section{Conclusion}

As a result, the success in anesthesia education can be increased by discipline and the teacher's appropriate use of the visual aids.

Peer-review: Externally peer-reviewed.

Author Contributions: Concept - G.B.; Design - M.B.; Supervision - M.B.; Funding - G.B.; Materials - M.B.; Data Collection and/or Processing - G.B.; Analysis and/or Interpretation - G.B.; Literature Review - M.B.; Writer G.B.; Critical Review - M.B.

Conflict of Interest: The authors declared no conflict of interest.

Financial Disclosure: The authors declared that this study has received no financial support.

\section{References}

1. Hotaman D, Yüksel-Şahin F. Öğretim Elemanı Coşkusunun Üniversite Öğrencilerinin Başarı Güdüsü Düzeyleri Üzerindeki Etkisi. Eğitim ve bilim 2010; 35: 89-102. 
2. Şen HŞ, Erişen Y. Öğretmen yetiştiren kurumlarda öğretim elemanlarının etkili öğretmenlik özellikleri. G.Ü. Gazi Eğitim Fakültesi Dergisi 2002; 22: 99-116.

3. Ülger N, Piyal B. Ankara sağlık meslek liseleri öğretmen ve öğrencilerinin meslek dersleri öğretiminde kullanılan yöntem, araç, kaynak ve sınav tekniklerine ilişkin görüşleri. Ankara Üniversitesi Tip Fakültesi Mecmuası 2000; 53: 173-179.

\section{Appendix 1}

\section{Anesthesia technician school second term questionnaire}

1. Are you satisfied with your department?

a) Yes

b) No

2. Have you found what you expected in the anesthesia department?
a) Yes
b) No

3. If no why?

4. Could you focus on the lessons as a student?
a) Yes
b) No

5. If no why?

6. Do you have difficulty in understanding the lessons?
a) Yes
b) No

7. Are the practice lessons sufficient?

a) Yes

b) No

8. Do you feel peaceful?
a) Yes
b) No

9. Do you feel happy?

a) Yes

b) No

10. Do you feel guilty? (Not studying enough, not being able to focus on the lessons, not being able to find time for the lesson)
a) Yes
b) $\mathrm{No}$

11. Can you follow the lessons sufficiently?
a) Yes
b) No

12. Would you be willing to take your theoretical lessons online, provided that practical lessons are conducted in the operating rooms? (To listen to the lectures at any place and at any time from the voice of your teacher with slides)

13. Your age?

14. Where have you graduated from?
a) Vocational high school
b) General high school 